1 Sandstead HH. Zinc deficiency: a public health problem? Am J Dis Child 1991;145:853-9

2 Castillo-Duran C, Vial P, Uauy R. Trace mineral balance during acute diarrhoea in infants. J Pediatr 1988;113:452-7.

3 Zinc Investigators' Collaborative Group. Therapeutic effects of oral zinc in acute and persistent diarrhoea in children in developing countries: pooled analysis of randomized controlled trials. Am J Clin Nutr pooled analysis

4 Zinc Investigators' Collaborative Group. Prevention of diarrhoea and pneumonia by zinc supplementation in children in developing countries: pooled analysis of randomized controlled trials. J Pediatr 1999;135:68997.

5 Health and Demographic Surveillance System Matlab. Registration of demographic events and contraceptive use 1998. Bangladesh: International Center for Diarrhoeal Disease Research, 2000. (ICDDR,B Scientific Center for Diant
Report No. 87.)

6 Baqui AH, Black RE, Arifeen SE, Hill K, Mitra SN, Sabir AA. Causes of childhood deaths in Bangladesh: results of a nationwide verbal autopsy study. Bull World Health Org 1998;76:161-71.

7 Sazawal S, Black RE, Bhan MK, Bhandari N, Sinha A, Jalla S. Zinc supplementation in young children with acute diarrhoea in India. $N$ Engl J Med 1995;333:839-44.

8 Roy SK, Tomkins AM, Akramuzzaman SM, Behrens RH, Mahalanabis D, Fuchs G. Randomised controlled trial of zinc supplementation in malnourished Bangladeshi children with acute diarrhoea. Arch Dis Child 1997;77:196-200.

9 Golden BE, Golden MHN. Zinc, sodium and potassium losses in the diarrhoeas of malnutrition and zinc deficiency. In: Mills CF, Bremner I, Chesters JK, eds. Trace elements in man and animals TEMA 5. Aberdeen: Rowett Research Institute, 1985:228-32.
10 Bettger WJ, O'Dell BL. A critical physiological role of zinc in the structure and function of biomembranes. Life Sci 1981;28:1425-38

11 Gebhard RL, Karouani R, Prigge WF, McClain CJ. Effect of severe zinc deficiency on activity of intestinal disaccharidases and 3-hydroxy-3methyl-glutaryl coenzyme A reductase in the rat. J Nutr 1983;113:855-9.

12 Shanker AH, Prasad AS. Zinc and immune function: the biological basis of altered resistance to infection. Am J Clin Nutr 1998;68(suppl 2):447-63S.

13 Fenwick PK, Agget PJ, McDonald D, Huber C, Wakelin D. Zinc deficiency and zinc repletion: effect on the response of rats to infection with Strongyloids ratti. Am J Clin Nutr 1990;52:166-72.

14 Sazawal S, Black RE, Bhan MK, Jalla S, Sinha A, Bhandari N. Efficacy of zinc supplementation in reducing the incidence and prevalence of acute diarrhoea-a community-based, double-blind, controlled trial. Am J Clin Nutr 1997;66:413-18.

15 Rosado JL, Lopez P, Munoz E, Martinez H, Allen LH. Zinc supplementation reduced morbidity, but neither zinc nor iron supplementation affected growth or body composition of Mexican preschoolers. Am J Clin Nutr 1997;65:13-9.

16 Ruel MT, Rivera JA, Santizo MC, Lonnerdal B, Brown KH. Impact of zinc supplementation on morbidity from diarrhoea and respiratory infections among rural Guatemalan children. Pediatrics 1997;99:808-13.

17 Sazawal S, Black RE, Jalla S, Mazumdar S, Sinha A, Bhan MK. Zinc supplementation reduces the incidence of acute lower respiratory infection in infants and preschool children: a double-blind controlled trial. Pediatrics 1998;102:1-5

(Accepted 24 June 2002)

\title{
Science commentary: What does zinc do?
}

\section{Abi Berger}

Adequate zinc intake is critical for health. Zinc deficiency affects cells of the immune system. It causes a reduction in the number $B$ lymphocytes and $T$ lymphocytes (CD4 lymphocytes in particular) through increased apoptosis and also reduces their functional capacity. The functions of the macrophage, another key immunological cell that engulfs and destroys bacteria, are also compromised. The production and potency of several cytokines, the central messengers of the immune system, are also perturbed by zinc deficiency. Many of these changes occur even in the early stages of deficiency.

Zinc plays a part in the maintenance of epithelial and tissue integrity through promoting cell growth and suppressing apoptosis and through its underappreciated role as an antioxidant, protecting against free radical damage during inflammatory responses. Thus, in the case of diarrhoea, multiple functions of zinc may help to maintain the integrity of the gut mucosa to reduce or prevent fluid loss. Notably, these responses can occur within 48 hours, much more rapidly than the direct effects of zinc on cellular development.

The recommended daily allowance is only $10 \mathrm{mg}$ elemental zinc, but many people in both developing and industrialised countries do not have this in their diet. ${ }^{1}$ Zinc deficiency is biochemically defined as a serum concentration of less than $9 \mu \mathrm{mol} / \mathrm{l}$. However, serum zinc concentrations may not fully reflect the physiological zinc status in an individual, and individuals with apparently normal serum concentrations may benefit from daily zinc supplements. ${ }^{2}$

\section{Benefits of supplementation}

This is clearly illustrated in several randomised controlled trials of zinc supplementation. A metaanalysis indicated that daily zinc supplementation can reduce the incidence of pneumonia by $41 \%$ and diarrhoea by $18 \%{ }^{3}$ A meta-analysis of trials of adjunctive zinc supplementation in children with diarrhoea reduced the duration of the illness by $24 \%{ }^{4} \mathrm{~A}$ trial of daily zinc supplementation in otherwise healthy children from New Guinea reduced the number of cases of malaria seen at a health clinic by $38 \%{ }^{5}$

There is also evidence that zinc supplementation could offer benefit to pregnant women and their babies. $^{6}$ One study showed that prenatal zinc supplementation can increase birth weight, ${ }^{7}$ and another indicated reduced incidence of diarrhoea and other morbidities in the infants. ${ }^{8}$ Babies who are small for gestational age also seem to benefit from taking daily zinc supplementation. A trial in India found that babies who received zinc from 1 month onwards were $60 \%$ less likely to die during infancy. ${ }^{9}$ Lastly, several studies indicate a potential role for zinc and supplements that contain zinc in improving immune status ${ }^{10}$ and health in elderly people. ${ }^{11}$ Zinc supplementation, therefore, seems be particularly critical during periods of immune development or degeneration: early childhood, pregnancy, and later life.

\section{Problems caused by too much zinc}

Taking too much daily zinc could also be a problem because, although it is not toxic, high doses can impair copper absorption. This can lead to copper deficiency with immunosuppression and other subtle and apparent adverse effects, especially for the mother and fetus during pregnancy. ${ }^{12}$ For this reason, doses more than twice the recommended daily allowance are not recommended and prenatal zinc supplements should contain copper, ${ }^{13}$ especially in populations with low mineral intakes.

1 Gibson RS, Vanderkooy PD, MacDonald AC, Goldman A, Ryan BA, Berry M. A growth-limiting, mild zinc-deficiency syndrome in some 
southern Ontario boys with low height percentiles. Am J Clin Nutr 1989;49:1266-75.

2 Black RE, Sazawal S. Zinc and childhood infectious disease morbidity and mortality. Br J Nutr 2001;85(suppl 2):S125-9.

3 Bhutta ZA, Black RE, Brown KH, Gardner JM, Gore S, Hidayat A, et al Prevention of diarrhea and pneumonia by zinc supplementation in children in developing countries: pooled analysis of randomized controlled trials. Zinc Investigators' Collaborative Group. J Pediatr 1999;135:689-97.

4 Bhutta ZA, Bird SM, Black RE, Brown KH, Gardner JM, Hidayat A, et al. Therapeutic effects of oral zinc in acute and persistent diarrhea in children in developing countries: pooled analysis of randomized controlled trials. Am J Clin Nutr 2000;72:1516-22.

5 Shankar AH, Genton B, Baisor M, Paino J, Tamja S, Adiguma T, et al. The influence of zinc supplementation on morbidity due to Plasmodium falciparum: a randomized trial in preschool children in Papua New Guinea. Am J Trop Med Hyg 2000;62:663-9.

6 Caulfield LE, Zavaleta N, Shankar AH, Merialdi M. Potential contribution of maternal zinc supplementation during pregnancy to maternal and child survival. Am J Clin Nutr 1998;68(2 suppl):S499-508.

7 Goldenberg RL, Tamura T, Neggers Y, Copper RL, Johnston KE, DuBard $\mathrm{MB}$, et al. The effect of zinc supplementation on pregnancy outcome. JAMA 1995;274:463-8.
8 Osendarp SJ, van Raaij JM, Darmstadt GL, Baqui AH, Hautvast JG, Fuchs GJ. Zinc supplementation during pregnancy and effects on growth and morbidity in low birthweight infants: a randomised placebo controlled trial. Lancet 2001;357:1080-5.

9 Sazawal S, Black RE, Menon VP, Dinghra P, Caulfield LE, Dhingra U, et al. Zinc supplementation in infants born small for gestational age reduces mortality: a prospective, randomized, controlled trial. Pediatrics 2001:108:1280-6.

10 Fortes C, Forastiere F, Agabiti N, Fano V, Pacifici R, Virgili F, et al. The effect of zinc and vitamin A supplementation on immune response in an older population. J Am Geriatr Soc 1998;46:19-26.

11 Girodon F, Galan P, Monget AL, Boutron-Ruault MC, Brunet-Lecomte P, Preziosi P, et al. Impact of trace elements and vitamin supplementation on immunity and infections in intitutionalized elderly patiens on ing

12 Keen CL, Uriu-Hare JY, Hawk SN, Jankowski MA, Daston GP, Kwik-Urib $\mathrm{CL}$, et al. Effect of copper deficiency on prenatal development and pregnancy outcome. Am J Clin Nutr 1998;7(suppl 5):S1003-11.

13 Institute of Medicine, Subcommittee on Nutritional Status and Weigh Gain During Pregnancy. Nutrition during pregnancy. Part 1:weight gain. Part 11:nutrition supplements. Washington, DC: National Academy Press, 1990.

\title{
Cross sectional, community based study of care of newborn infants in Nepal
}

\author{
David Osrin, Kirti M Tumbahangphe, Dej Shrestha, Natasha Mesko, Bhim P Shrestha, \\ Madan K Manandhar, Hilary Standing, Dharma S Manandhar, Anthony M de L Costello
}

\begin{abstract}
Objective To determine home based newborn care practices in rural Nepal in order to inform strategies to improve neonatal outcome.

Design Cross sectional, retrospective study using structured interviews.

Setting Makwanpur district, Nepal.

Participants 5411 married women aged 15 to 49 years who had given birth to a live baby in the past year.

Main outcome measures Attendance at delivery, hygiene, thermal care, and early feeding practices. Results 4893 (90\%) women gave birth at home. Attendance at delivery by skilled government health workers was low $(334,6 \%)$, as was attendance by traditional birth attendants $(267,5 \%)$. Only $461(8 \%)$ women had used a clean home delivery kit, and about half of attendants had washed their hands. Only 3482 (64\%) newborn infants had been wrapped within half an hour of birth, and 4992 (92\%) had been bathed within the first hour. 99\% (5362) of babies were breast fed, 91\% (4939) within six hours of birth. Practices with respect to colostrum and prelacteals were not a cause for anxiety.

Conclusions Health promotion interventions most likely to improve newborn health in this setting include increasing attendance at delivery by skilled service providers, improving information for families about basic perinatal care, promotion of clean delivery practices, early cord cutting and wrapping of the baby, and avoidance of early bathing.
\end{abstract}

\section{Introduction}

Although infant mortality has fallen in many developing countries over the past two decades, the rate of fall may be slowing. ${ }^{1}$ One reason is the resistant contribu- tion of neonatal mortality, which has remained fairly steady over this period..$^{2}$ For many mothers, health care during and after childbirth is virtually nonexistent, and in 2000, an estimated 53 million women in developing countries gave birth without professional help. ${ }^{4}$

The World Health Organization guidelines for essential newborn care encompass cleanliness, thermal protection, initiation of breathing, early and exclusive breast feeding, eye care, immunisation, management of illness, and the care of low birthweight infants. ${ }^{5}$ For a mother and her family, this means preparing for birth, choosing a safe place for delivery, keeping the process clean, avoiding the cold, breast feeding early and exclusively, and understanding (and reacting to) potential danger signs. Our understanding of what happens at home and how to change behaviour is limited. The aim of the present study was to describe newborn care practices quantitatively in the cohort of women recruited to the trial.

\section{Participants and methods}

\section{Setting}

Nepal has a population of 23.4 million with more than 60 ethnic groups. The landscape tiers down from the Himalayas, through middle hills, to plains in the south. The population is poor, and there are limited communications and infrastructure. The gross national product per head is about $\$ 220$ (£145, €223), ${ }^{7}$ the human development index is $0.378,{ }^{8}$ life expectancy is 58 years, about $60 \%$ of adults are illiterate, ${ }^{7}$ the total fertility rate is 4.8 in rural areas, and early marriage and adolescent pregnancy are common. ${ }^{9}$

Nepal's estimated neonatal mortality rate is $50 / 1000$ live births and accounts for two thirds of the infant mortality rate $(79 / 1000))^{9}$ Less than half of pregnant women attend for any antenatal care, ${ }^{9-13}$ and
ELPS

This is an abridged version; the full version is on bmj.com

International

Perinatal Care Unit, Institute of Child Health, Universit College London, London

WC1N 1EH

David Osrin clinical research fellow

Natasha Mesko research fellow

Anthony M de L

Costello

professor

Mother Infant Research Activities, GPO Box 921,

Kathmandu, Nepal

Kirti M

Tumbahangphe senior monitoring and surveillance officer

Dej Shrestha senior data management officer Bhim P Shrestha programme manager

Dharma S

Manandhar

director

Nepa

Administrative Staft

College,

Kathmandu, Nepal

Madan K

Manandhar

director, centre for

local governance

continued over

BMJ 2002;325:1063-6 